\title{
Faraday's Laws and the Flipped Classroom: A proposal for distance learning
}

\author{
Leis de Faraday e a sala de aula invertida: Uma proposta para o ensino a distância \\ Las leyes de Faraday y el aula invertida: Una propuesta para la educación a distancia
}

Received: 07/11/2021 | Reviewed: 07/21/2021 | Accept: 07/25/2021 | Published: 08/01/2021

\author{
Tadeu Luiz Gomes Cabral \\ ORCID: https://orcid.org/0000-0003-3222-065X \\ Federal Fluminense University, Brazil \\ E-mail: tadeucabral@id.uff.br \\ Natany Dayani de Souza Assai \\ ORCID: https://orcid.org/0000-0002-0851-9187 \\ Federal Fluminense University, Brazil \\ E-mail: natanyassai@id.uff.br \\ Sandro Lucas Reis Costa \\ ORCID: https://orcid.org/0000-0003-4199-9810 \\ State University of Londrina, Brazil \\ E-mail: lucasc_1995@outlook.com
}

\begin{abstract}
The present article describes a proposal for teaching Faraday's Laws, within electrolysis content, using the Flipped Classroom methodology. This proposal was developed in completely distance learning lessons, in Chemistry, with two High School classes in the third year. In addition, this article conducts a bibliographic mapping of the presence of previous works with the methodology and contents discussed. The mapping of articles was important to reveal a gap in the literature regarding the presence of studies involving Faraday's Laws and the Flipped Classroom. With the absence of previous articles, this article developed a pioneering proposal in the field, where the Flipped Classroom highlighted the development of conceptual contents about Faraday's Laws and stimulated the active participation of students in distance learning. Finally, with the work developed, the potential of the Flipped Classroom as a methodology to be used in Chemistry Teaching was noted, mainly in the teaching of Faraday's Laws in electrochemistry.
\end{abstract}

Keywords: Flipped classroom; Electrolysis; Faraday's laws.

\section{Resumo}

O presente trabalho descreve uma proposta para o ensino de Leis de Faraday, dentro do conteúdo de eletrólise, utilizando a metodologia da Sala de Aula Invertida. Tal proposta foi desenvolvida em aulas totalmente remotas da disciplina de Química com duas turmas do terceiro ano do Ensino Médio. Além disso, o presente artigo faz um mapeamento bibliográfico sobre a presença de trabalhos anteriores com a metodologia e os conteúdos comentados. O levantamento dos artigos foi importante para demonstrar uma lacuna na literatura de trabalhos com os assuntos de Leis de Faraday e Sala de Aula Invertida. Com a ausência de artigos anteriores, a presente proposta desenvolveu uma proposta pioneira no ramo, onde foi notado o destaque da Sala de Aula Invertida no desenvolvimento dos conteúdos conceituais sobre as Leis de Faraday e no estímulo à participação ativa do aluno nas aulas remotas. Por fim, com o trabalho desenvolvido notou-se a potencialidade da Sala de Aula Invertida como uma metodologia a ser utilizada no Ensino de Química, principalmente, no ensino das Leis de Faraday na eletroquímica.

Palavras-chave: Sala de aula invertida; Eletrólise; Leis de faraday.

\section{Resumen}

El presente artículo describe una propuesta para la enseñanza de las Leyes de Faraday, dentro de los contenidos de electrólisis, utilizando la metodología Flipped Classroom. Esta propuesta se desarrolló en lecciones de Química completamente a distancia con dos clases de Bachillerato en el tercer año. Además, este artículo realiza un mapeo bibliográfico de la presencia de trabajos previos con la metodología y contenidos discutidos. El mapeo de artículos fue importante para revelar una brecha en la literatura con respecto a la presencia de estudios relacionados con las leyes de Faraday y el aula invertida. Con la ausencia de artículos anteriores, este artículo desarrolló una propuesta pionera en el campo, donde el Flipped Classroom destacó el desarrollo de contenidos conceptuales sobre las Leyes de Faraday y estimuló la participación activa de los estudiantes en la educación a distancia. Finalmente, con el trabajo desarrollado, se constató el potencial del Aula Invertida como metodología para ser utilizada en la Enseñanza de la Química, principalmente en la enseñanza de las Leyes de Faraday en electroquímica.

Palabras clave: Aula invertida; Electrólisis; Leyes de faraday. 


\section{Introduction}

There is a wide range of discussions (Merçon et al., 2012; Vieira, Melo \& Viana, 2018) regarding the disruption of characteristics of traditional education, including in Chemistry Teaching. In this traditional teaching model, lessons are expository lectures and conducted mechanically, in which students' prior knowledge is not considered and they are seen as passive subjects in the teaching and learning processes. The didactic resources and strategies used in this teaching model are generally not varied and the contents covered are often not related to the daily lives of students, being summarized as involving, mostly, memorization and repetition (Vieira \& Guimarães, 2015).

In Virtual Learning Environments (VLE), especially in distance learning, Chemistry Teaching can also suffer from the same problems, following the traditional model. Other barriers can also be negative aspects in the distance learning model, for example: a lack of professional training in developing distance teaching, a lack of free memory capacity on some platforms, difficulties in accessing the internet, low student participation and interaction in VLEs, among other problems associated with distance education (Fiori \& Goi, 2020).

The Flipped Classroom (FC) is a didactic strategy that brings the idea of inversion to the classroom. Basically, what is done in class is now done outside the classroom and what was done at home is now done in the class. The FC explores the participative and active dynamics of students during learning processes, which is a differentiating aspect of this strategy (Bergmann, Overmeyer \& Willie, 2012).

The FC is a strategy that has been used in the broader movement to implement active methodologies. The FC proposal has presented great opportunities, from an educational point of view, especially with the dissemination of technology in education and the inclusion of educational technologies in the teaching and learning processes in the classroom (Valente, 2018).

In this sense, the present study approaches considerations about the insertion of the FC as a methodological possibility for Chemistry Teaching, with a view to overcoming some gaps in distance education. The proposal, presented in this article, is aimed at teaching the content of Faraday's Laws (FL) for students in the 3rd year of High School, with the methodology of the Flipped Classroom (FC) in distance education.

Thus, this study aims to:

I) Present a brief mapping regarding the content of Faraday's Laws and the Flipped Classroom methodology;

II) Describe and analyze a proposal for teaching the content of Faraday's Laws based on a Flipped Classroom for distance learning.

\section{Theoretical Foundation}

\subsection{Distance education and tools for distance lerning}

The teaching modality called Distance Education (DE) is the form of teaching and learning mediated by technologies, allowing the teacher and the student to be separated temporally and/or spatially during classes. This form of teaching takes on specific aspects that make it necessary to use different strategies and tools that are not always common in face to face education (Silva, Santos \& Silva, 2019).

Primarily, DE can occur in two ways: synchronous or asynchronous. The asynchronous way is linked to communication that takes place with a time interval between the sending, receiving and understanding of a given study material. In the synchronous form, this time interval is reduced in such a way that the student and teacher must be connected simultaneously, as in the case of chat rooms and lessons which are broadcast live (Mello, 2009). 
According to Silva, Santos and Silva (2019), Distance Learning, conducted synchronously or asynchronously, takes place through VLEs, with chats, forums, hypertexts and so on. The necessary teaching resources for the lessons can be: texts, video classes, assessment activities, among others. It is in VLEs that digital tools are integrated with educational tools in order to provide active participation of students and promote meaningful learning.

According to Giordan (2008), digital tools, particularly in Science education, have a relevant potential for teaching, as they help in the transposition and elucidation of natural phenomena in a digital way. Therefore, these resources can help in the articulation of curriculum proposals with dynamic learning that understands the student as an active subject in the teaching and learning processes.

Different tools can be used in the VLEs in order to increase and strengthen the pedagogical activities. Barão (2007) discusses some of these in the following topics:

a) the use of hypertext - allows reading in the order the user prefers, as the subjects are related through links that refer

to other complementary and explanatory texts, images, icons, etc.

b) the integration of technologies, with the simultaneous use of new technologies: TV, Internet and telecommunications.

c) content storage, databases with materials to support the course.

d) constant content feedback, constant updating of materials, texts, recommendations of updated websites.

e) the constitution of communication networks, as interactive tools: forums, chats, discussion lists (Barão, 2016, p. 8, our translation).

Among the various tools, simulation software merits special attention for the potential in Chemistry Teaching, as it is able to build dynamic models and simplify the real world, offering the possibility for the student to develop hypotheses, test them, analyze results and refine concepts. These resources can complement the reading and discussions in the teaching process, creating conditions for the student to make the transition between simulation and interpretation of the phenomenon in the real world, without a mechanical learning of the concepts (Melo \& Melo, 2005).

In Distance Education, the main source of knowledge is the reading of texts that supports the physical presence of the teacher. There is a wide typology of texts and the use of these materials must be planned in order to contemplate the objectives of the lesson, the different perspectives of knowledge and the relationships of the contents with the daily lives of students (Neder, 2009). Another very prominent tool in the Distance Learning model is the video class. This feature is important for understanding the concepts in the student's learning time, which can provide greater interest to the student. According to Carvalho and Candeias (2016):

The use of these video classes provide students with different perceptions of the content, where the lessons are presented in a multisensory way, as they use video, audio and images, making the student more interested in the content, encouraging him/her to research more about the subject. In this way, the student will feel more stimulated to learn, unlike traditional classes that are guided only by written and spoken language (Carvalho \& Candeias, 2016 , p. 8 , our translation).

The proper use of video classes, as a didactic resource aimed at breaking away from traditional pedagogical practices, must be centered on the process, otherwise the tool may end up being a simple display of contents that are disconnected from the reality of the students.

In this scenario, of having the student as the protagonist in the learning process in VLEs, both in synchronous and asynchronous moments, it is necessary to choose a didactic strategy that uses tools that value the student as an active subject in teaching and break with traditional perspectives of Distance Education. 


\subsection{The Flipped Classroom}

The Flipped Classroom is a b-learning approach started in the 1990s (Moran \& Milsom, 2015). B-learning, or blended learning, is a derivative of e-learning, and refers to an education system in which most of the content is presented without students being physically present at the school. Despite the creation of the approach in the 1990s, according to Lopes, Gouveia and Reis (2019), the FC started to consolidate itself, in general methodological aspects, with a more delimited structure with clearly defined educational objectives in 2006 with the encouragement of two North American teachers, John Bergmann and Aaron Sams, working in secondary education.

One of the viable teaching strategies that enable the varied use of teaching resources in VLEs is the Flipped Classroom (FC). In this strategy, students can build their own paths to knowledge even before the lesson starts. This incentive to research is able to enrich and develop the cognitive ability of students to seek, create, evaluate, analyze, build, describe and later apply their knowledge in a practical moment of the lesson (Leite, 2017).

In short, this didactic strategy is based on reversing roles. What was done at home, such as problem solving, will be done in class, and what was done in class, such as exposition, reading and reflection of the contents, will be done previously and at home (Bergmann, Overmeyer \& Willie, 2012).

The main focus in the Flipped Classroom must be the student. The inversion should be more linked to the mentality of shifting the attention from the teacher to the student and his/her learning. Therefore, this approach has the student as the protagonist and responsible for his/her own study of the contents and themes, and the lesson takes on the role of applying knowledge in practical terms (Bergmann, Overmeyer \& Willie, 2012).

The class time is not limited to just putting the contents into practice through problem solving. Some didactic resources that enable the carrying out of activities and experiments can also be applied, which work as auxiliary tools for the construction of knowledge. Thus, the teaching and learning processes can become increasingly effective (Schultz et al., 2014).

For Valente (2018):

In the flipped classroom approach, the content and instructions received are studied online, before the student attends the class, through technology, more specifically, virtual learning environments. The classroom becomes the place to work on the contents that have already been studied, and carry out practical activities such as problem solving and projects, group discussions and laboratories. However, the fact that the activities that the student performs online can be registered in the virtual learning environment creates the opportunity for the teacher to make an accurate diagnosis of what the learner was able to perform, the difficulties encountered, their interests and the learning strategies used. Based on this information, the teacher, along with the student, can suggest activities and create fully personalized learning situations. (Valente, 2018, p. 27, our translation).

According to Schmitz (2016), the FC model favors the development of individual skills, self-study, critical thinking and self-learning. According to Ennis (1985, p. 45) critical thinking is a form of "reflective and rational thinking that focuses on defining what to believe". For Costa, Obara and Broietti (2020), these skills are relevant for science learning, particularly critical thinking, as this skill is related to the subject's ability to become a participating and active citizen in society, through scientific modernity.

In the $\mathrm{FC}$, role changes and time restructuring allow class activities to have high cognitive work. The fact that the exposition of contents or the understanding of basic information is done outside the class, by the student, makes it possible for him/her to prepare for active learning activities during the class time.

In a FC, learning speed is a relevant fact, as each student will be able to define his/her learning time. In general, this possibility of choice motivates the student to gain confidence in the learning process, leading to a significant development of cognitive and social-emotional skills (Schmitz, 2016). Figure 1 presents a layout of the FC. 
Figure 1: Basic Layout for the Flipped Classroom ${ }^{1}$.

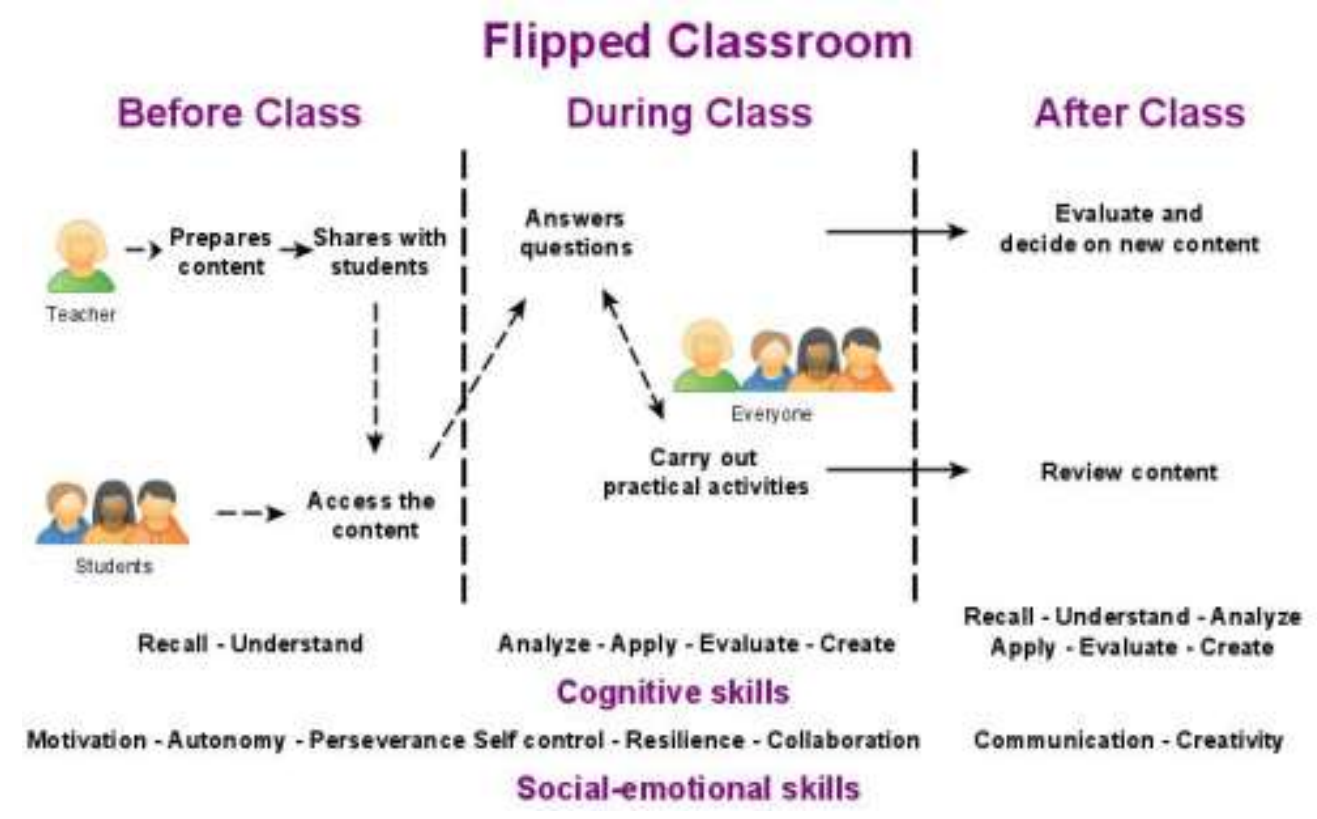

Source: adapted from Schmitz (2016).

From Figure 1, it is noted that before the class, students have access to the content and develop cognitive skills by understanding and recalling the subjects provided by the teacher. At that time, the social-emotional skills promoted are motivation, autonomy and perseverance. During class, students carry out practical activities and have their questions answered by the teacher. The cognitive skills developed are the ability to analyze, apply, evaluate and create; the social-emotional skills are self control, resilience and collaboration. At the last moment, after class, a review and evaluation of the contents is carried out. At that time, students are able to develop all previous cognitive skills. In addition, there is the promotion of socialemotional skills, with communication and creativity being added.

Given these considerations about the Flipped Classroom, it is demonstrated that the aforementioned didactic strategy is relevant to develop the contents of Chemistry involved in Faraday's Laws, when teaching is being taken place remotely, both in a synchronous mode or asynchronous way.

\subsection{Faraday's Laws and the Flipped Classroom - A Brief Mapping}

The study of electrochemistry is of paramount importance for Chemistry, since the contents of this subject are present in several facts, applications and everyday objects that students have contact with. Learning the concepts associated with electrochemistry is fundamental for the development of a critical and active citizen in society, with a critical and reflective look at scientific, social, technological and environmental issues (Braga, 2019). One of the highlighted subjects in electrochemistry is Faraday's Laws of electrolysis, as their understanding allows the student to develop quantitative interpretations of an electrolytic process.

Faraday's Laws of electrolysis provide important markers on concepts involved in electrodeposition. The first law elucidates the proportionality between the mass deposited on the electrode and the amount of electricity that passes through the solution. The second law states that regardless of the chemical species linked together, the same element has the same electrochemical equivalent. (Pinto, 2018).

\footnotetext{
${ }^{1}$ This figure was created with the yEd Graph Editor application: https://www.yworks.com/yed
} 
According to Braga (2019), the contents related to electrochemistry presente certain difficulties for students to understand. Based on the concerns that originated this study, a mapping of the academic productions of periodicals was carried out, aiming at the content of Faraday's Laws and the FC methodology. This mapping was based on the instrument proposed by Assai, Arrigo and Broietti (2018), which presents a representative list of 56 journals in the field for conducting mappings of the literature, which include national journals with A1, A2 and B1 Qualis (the highest jornal classifications) in the 2012-2016 quadrennial evaluation, selected in a meticulous movement of using some search filters (Science, Teaching, Chemistry and Education) associated with Science Education. For that, the "Search" tool was used, and the search field called "search term in all categories" was also used, through inserting the keywords "faraday" (focused on teaching electrochemistry) and "flipped classroom"; present in the title, abstract and/or keywords of the articles.

Overall, the mapping was carried out in 33 journals of the following filters: Science, Teaching and Chemistry, listed in the work of Assai, Arrigo and Broietti (2018). Table 1 presents a list with the articles found, the subjects covered and the respective target audiences.

Table 1: List of publications found in the mapping.

\begin{tabular}{|c|c|c|}
\hline Article & Subject & Target Audience \\
\hline $\begin{array}{l}\text { Scheunemann, C. M. B.; Almeida, C. M. M.; \& Lopes, P. T. C. (2020). Sala de Aula Invertida no } \\
\text { Ensino e Aprendizagem de Anatomia Humana: Análise do Desempenho e Percepções de } \\
\text { Acadêmicos da Área da Saúde. Acta Scientiae, 22(1), 151-174. }\end{array}$ & $\mathrm{FC}$ & Higher Education \\
\hline $\begin{array}{l}\text { Oliveira, E. S., Reis, N. A., \& Silva, E. L. (2018). Contextualização histórica dos estudos de } \\
\text { Faraday sobre eletricidade e matéria: contribuições para o Ensino de Ciências. Revista de Ensino } \\
\text { de Ciências e Matemática, 9(3),87-105. }\end{array}$ & $\begin{array}{l}\text { Bibliographi } \\
\text { c research }\end{array}$ & $\begin{array}{l}\text { There is no } \\
\text { specific Target } \\
\text { Audience }\end{array}$ \\
\hline $\begin{array}{l}\text { Santos, C. L., \& Barros, A. S. (2020). Uma análise da estratégia didática em sala de aula } \\
\text { invertida no processo ensino e aprendizagem de genética em turmas do ensino médio técnico } \\
\text { integrado de uma escola pública. RENCIMA, 11(6), 716-740. }\end{array}$ & $\mathrm{FC}$ & $\begin{array}{l}\text { Technical High } \\
\text { School }\end{array}$ \\
\hline $\begin{array}{l}\text { Honório, H. L. G., Scortegagna, L., \& David, J. M. N. (2019). Processo para Implementação da } \\
\text { Metodologia da Sala de Aula Invertida com Elementos de Colaboração. Revista Brasileira de } \\
\text { Ensino de Ciência e Tecnologia, 12(3), 110-130. }\end{array}$ & $\mathrm{FC}$ & $\begin{array}{l}\text { Elementary } \\
\text { School }\end{array}$ \\
\hline $\begin{array}{l}\text { Honório, H. L. G., \& Scortegagna, L. (2017). Invertendo a Sala de Aula: Processo para a } \\
\text { implementação da metodologia sala de aula invertida com elementos de colaboração no ensino } \\
\text { de matemática. Revista de Educação Ciências e Matemática, 7(2), 203-2019. }\end{array}$ & $\mathrm{FC}$ & $\begin{array}{l}\text { Elementary } \\
\text { School }\end{array}$ \\
\hline $\begin{array}{l}\text { Calheiros, K. J. M., David, J. M. N., \& Scortegagna, L. (2020). Processo para a implementação } \\
\text { da sala de aula invertida com foco nos elementos de comunicação. Revista de Educação, } \\
\text { Ciências e Matemática, 10(2), 259-271. }\end{array}$ & $\mathrm{FC}$ & $\begin{array}{l}\text { Elementary } \\
\text { School }\end{array}$ \\
\hline $\begin{array}{l}\text { Faria, A. F., \& Vaz, A. M. (2020). Tarefas para Aulas Invertidas: Relato de Experiência Docente } \\
\text { com Deveres de Casa On-line em Curso de Física. Caderno Brasileiro de Ensino de Física, } \\
\text { 37(2), 729-750. }\end{array}$ & $\mathrm{FC}$ & High School \\
\hline $\begin{array}{l}\text { Bacelar, F. A., Rios, M. F., \& Carvalho, T. M. X. B. (2019). Proposta de ensino aprendizagem a } \\
\text { ser aplicada em disciplinas de Engenharia Civil na Universidade de Fortaleza. Revista de Estudos } \\
\text { e Pesquisas sobre Ensino Tecnológico (EDUCITEC), 5(10), 403-413. }\end{array}$ & $\mathrm{FC}$ & Higher Education \\
\hline $\begin{array}{l}\text { Ribeiro, L. C. V. (2018). Testando novas metodologias de aprendizagem para o ensino de } \\
\text { embriologia humana: relato de experiência e percepção dos discentes. Revista Docência do } \\
\text { Ensino Superior, } 8(1), 151-165 \text {. }\end{array}$ & $\mathrm{FC}$ & Higher Education \\
\hline $\begin{array}{l}\text { Martins, E. R., Gouveia, L. M. B., Afonseca, U. R., \& Geraldes, W. B. (2019). Comparação entre } \\
\text { o modelo da sala de aula invertida e o modelo tradicional no ensino de matemática na perspectiva } \\
\text { dos aprendizes. Experiências em Ensino de Ciências, } 14(1), 522-530 \text {. }\end{array}$ & $\mathrm{FC}$ & Technical Course \\
\hline
\end{tabular}




\begin{tabular}{|l|c|c|}
\hline $\begin{array}{l}\text { Scheunemann, C. M. B., \& Lopes, P. T. C. (2020). Análise De Questões Elaboradas por } \\
\text { Acadêmicos de Anatomia Humana em uma Estratégia de Sala de Aula Invertida. Experiências } \\
\text { em Ensino de Ciências, 15(2), 644-660. }\end{array}$ & FC & Higher Education \\
\hline $\begin{array}{l}\text { Evangelista, Á. M., \& Sales, G. L. (2018). A sala de aula invertida (flipped classroom) e as } \\
\text { possibilidades de uso da plataforma professor online no domínio das escolas públicas estaduais } \\
\text { do Ceará. Experiências em Ensino de Ciências Cuiabá, 13(5), 566-583. }\end{array}$ & FC & Teacher Education \\
\hline $\begin{array}{l}\text { Paula, S. L., Albuquerque, M. C. F., Granja, B. C. A., \& Santos, C. F. S. O. (2018). } \\
\text { Metodologias ativas: uma ação colaborativa para a formação de multiplicadores. Convergências } \\
\text { em Ciência da Informação, 1(2), 160-167. }\end{array}$ & FC & Higher Education \\
\hline
\end{tabular}

Source: Authors.

From Table 1, it is noted that the search resulted in 13 articles dedicated to the topics of interest (Faraday's laws or the FC). It is noteworthy, at first glance, that all selected articles were published in the last 4 years, that is, from 2017 onwards. Thus, we consider that the FC, as a recent methodological strategy, proposed in the last decade (Bergmann, Overmeyer \& Willie, 2012), took a few years to present results in national publications in Brazil.

In addition, of the 13 selected articles, only one addresses the topic of Faraday's Laws. Oliveira, Reis and Silva (2018) developed a bibliographical research on the studies of Michael Faraday and his possible contribution to Science Education, through a contextualized approach. Despite this, there is no in-depth discussion on the implications for Chemistry Teaching, specifically, or on the intentionality in relation to aspects of the study of Electrochemistry and a possible development in the school environment.

Of the remaining 12 articles that present the FC as a methodological proposal, none is dedicated to the teaching of chemistry in High School. It is noted that, among the 12 selected articles, most of these (5 publications) are aimed at Higher Education. High School has only two articles that report on the FC, one of which is in a Technical High School. Therefore, there is a lack of studies in which the target audience are high school students and it is evident the need to develop new studies that address this group.

It is worth noting that, of all the selected articles, no teaching proposal was found that used the FC to work chemical content, much less a proposal for teaching Faraday's Laws focused on electrolysis content. In addition, we reiterate the deficiency of a proposal for Basic Education, more specifically for High School, since there is a predominance of proposals for Higher and Technical Education, corroborated by Table 1.

Therefore, it is necessary to prepare a proposal aimed at teaching electrochemistry, especially Faraday's Laws, given its importance in various processes, such as metal recycling, electrodeposition of protective layers on surfaces, etc., in order to overcome the challenges faced in student learning of these concepts.

\section{Methodology}

The present study was carried out with two third-year High School classes in a public school in the city of Volta Redonda, in the state of Rio de Janeiro. Due to the COVID-19 pandemic, the entire proposal was performed in the distance learning model and the Flipped Classroom strategy was used for teaching Faraday's Laws. The sequences adopted, along with the three steps of the FC, were divided into synchronous and asynchronous moments. Table 2, presented below, describes the nature of each step, the resources used and the main function of each step. 
Table 2: FC Steps and their respective descriptions.

\begin{tabular}{|c|c|c|c|}
\hline & Before Class (BC) & During Class (DC) & After Class (AC) \\
\hline Form & Asynchronous & Synchronous & Asynchronous \\
\hline $\begin{array}{l}\text { Teaching } \\
\text { resources used }\end{array}$ & $\begin{array}{l}\text { Video class, didactic text and list of } \\
\text { exercises }\end{array}$ & Slides, software and exercises & $\begin{array}{c}\text { All previously available materials } \\
\text { and a questionnaire }\end{array}$ \\
\hline VLEs used & YouTube and Google Classroom & Google Meet & $\begin{array}{c}\text { Google Classroom and Google } \\
\text { Forms }\end{array}$ \\
\hline Main function & $\begin{array}{l}\text { In this first part (BC), the material } \\
\text { with the content of Faraday's Laws } \\
\text { is made available to students so that } \\
\text { they can carry out a previous study, } \\
\text { in an autonomous way. }\end{array}$ & $\begin{array}{l}\text { The DC step is dedicated to a } \\
\text { brief review of the concepts } \\
\text { previously studied, the } \\
\text { clarification of questions and } \\
\text { applications in problem situations. }\end{array}$ & $\begin{array}{l}\text { The last step (AC) is aimed at } \\
\text { reviewing the contents and } \\
\text { evaluating them. }\end{array}$ \\
\hline
\end{tabular}

Source: Authors.

As noted in Table 2, in step BC, materials are made available for students to base themselves and deepen the content of Faraday's Laws. In the second step of the FC, step DC, the focus is on answering questions and solving problem situations. The third step, AC, is the moment when concepts are reviewed and evaluated.

It is noteworthy that there were some limitations, established by the school, for carrying out this research. The limits were related to the amount of time in the video class; the number of pages of the didactic text; the amount of exercises to be made available before the class; and the number of questions in the evaluative questionnaire. All these points were thought out in order not to generate an overload of materials for the students.

In view of these points, a video class of approximately 10 minutes was prepared for stage $\mathrm{BC}$, with a conceptual explanation and a mathematical application of Faraday's Laws; a 4-page didactic text with the same principle as the video class; a list of exercises with 5 contextualized questions about FLs; and a file with the written resolution of these questions. All materials were made available to students a week before class, with the aim of exploring cognitive and social-emotional skills and encouraging students' self-study.

The DC step is dedicated to the synchronous moment. The class itself was conducted in approximately 50 minutes and the didactic sequence for it is shown in Table 3, explained below.

Table 3: Description of the Synchronous DC step.

\begin{tabular}{|c|c|c|}
\hline & Description & Duration \\
\hline $1 \mathrm{st}$ & $\begin{array}{c}\text { Conducting a brief review of the key concepts of electrochemistry and knowledge } \\
\text { related to FLs addressed in the video class. }\end{array}$ & 10 minutes \\
\hline 2nd & Carrying out a simulation of an electrolysis process using the software ${ }^{2}$. & 15 minutes \\
\hline $3 \mathrm{rd}$ & $\begin{array}{l}\text { Solving problem situations in order to put into practice the knowledge learned and } \\
\text { the facts observed during the simulation. }\end{array}$ & 20 minutes \\
\hline 4th & Answering questions. & 5 minutes \\
\hline
\end{tabular}

Source: Authors.

2 Chemistry Simulations Electrolysis, Pearson Education, 2014. Available at: <https://media.pearsoncmg.com/bc/bc_0m edia_chem/chem_sim/html5/Electro/Electro.php>, accessed June 20, 2021. 
The purpose of the synchronous class is to recall the concepts studied in step BC, clarify questions and, mainly, put into practice the knowledge about the first and second FLs. For this, the simulation software is essential, as it allows checking the laws, as well as building situations where there is the possibility of reflecting on the observed and studied facts, in order to make predictions for the simulation.

Finally, in the last step of the FC, the AC, a review of concepts and an evaluation is carried out, using a form available on Google Classroom. In this questionnaire, there are two questions about the contents related to FLs and questions that have the purpose of identifying the students' opinion about the proposal.

It should be noted that, at all times, the students had the opportunity to contact the teacher through Google Classroom and/or through messages in the WhatsApp application, to clarify any possible questions regarding the content or the sequence of classes.

Therefore, data were collected through the questionnaire applied in the AC step and were analyzed quantitatively in this investigation. The data refer to responses from 41 students to the questions on the form. It was possible to interpret these answers and infer results about the implementation of the proposal and the teaching of chemical concepts involved in the classes.

\section{Results and Discussion}

According to the proposed class applied using the $\mathrm{FC}$, it was possible to obtain results from the three steps (BC, DC and AC) of the chosen pedagogical approach. Therefore, with the interpretation of these data, it was possible to obtain results and reflections on the given proposal and the use of the FC in the teaching of Faraday's Laws in High School.

Leite (2017) through a review of publications on the theme "Flipped Classroom" on Google Scholar evidences an incipient and scarce movement of research available in Portuguese involving this modality of hybrid teaching until the current year. Discussions about this modality entered the discussions with greater emphasis and multiplied due to the educational changes imposed by Covid 19 from the year 2020 and forward. In this sense, Leite (2017) presents some possibilities for the implementation of the Flipped Classroom in the teaching of Chemistry, suggesting tools to be used prior to the synchronous and collective moment, namely:

(1) The use of digital teaching resources, relevant to the content and accessible to all students. The use of software and hypermedia can contribute to student learning when using these resources. For example, use of simulations involving chemical concepts;

(2) The use of texts and videos (which can be obtained from the Web) with a focus on content to be discussed in the classroom. It is clear that videos have great potential for teaching (Silva, Leite \& Leite, 2016), facilitating learning for those involved. It must be emphasized that long videos are not the most suitable as to not discourage students. Ex.: videos with representations of chemical reactions;

(3) The creation of forums for students' discussions, thus providing the sharing of their ideas and definitions about the content to be discussed later in the classroom;

(4) The elaboration of quizzes, which, when answered by the students, "require" them previously study the content, which is therefore necessary for their learning;

(5) The use of games, which gives rise to an environment of "competition", thus involving them in the quest to overcome challenges and, in this context, to learn. (Leite, 2017, p. 1594).

For the present investigation, we chose to select tools referring to items 1-3 suggested by Leite (2017), since a variety of digital didactic resources were used, namely: Classroom, Youtube, Google Meet, and Whatsapp.

With regard to item (2), for step BC (before the class), the video class (available on Youtube), didactic text and list of exercises were used. These tools are mandatory didactic materials, that is, they were elaborated in compliance with the requirements of the school in which the proposal was implemented, in the context of Emergency Remote Teaching (ERE). It is noteworthy that attention was given to the duration of the video (not exceeding 20 minutes), to keep the students' attention. 
Students could answer their questions through the virtual learning environment platform used, in this case the google classroom, or even through the Whatsapp group, sharing ideas and/or questions about the content and activities, checking the existence of item 3 proposed by Leite (2017).

It was expected that didactic resources made available in step BC would be of great value to students, since, through the access to these materials, students have their different learning speeds considered, promoting greater motivation for research and reflection on the chemical content. From this perspective, for this first asynchronous step to be effective and fulfill its functionalities, it was necessary for students to access the available teaching materials.

From the analysis of the 41 students' responses to the form (available at the AC moment), it was possible to see that most students performed the previous study, required in step BC. According to the graph in figure 2, in total, $90.2 \%$ of students reported having consulted the materials. In a more refined analysis of the access to the materials, it was possible to identify that only $33 \%$ of the students accessed all the materials made available, $19.5 \%$ of them consulted only the video class and $39.2 \%$ read only the didactic text provided. Thus, it can be seen that adding the percentage of students who accessed all the materials and students who consulted only the textbook, $72.2 \%$ is reached. This value expresses the importance of the didactic text in the previous study of the contents, since most students consulted it in the step BC.

Figure 2: Graph with information regarding access to teaching materials available BC.

\section{What material was accessed?}

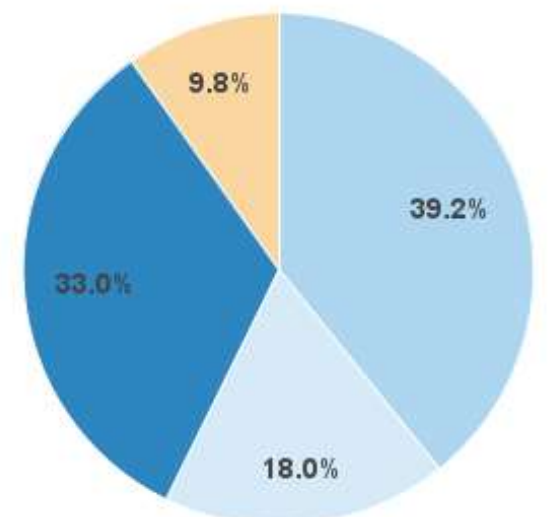

Only the didactic text was accessed

Only the video class was accessed

All materials were accessed

No material was accessed

Source: Authors.

As the questionnaire was applied only at the AC step, it was not possible to infer, in more detail, data on learning, motivation and difficulties encountered by students during the first asynchronous part. Therefore, this point can be considered as an aspect of adjustment in the application of the proposal in the future, as it would be necessary to carry out a more detailed research of these points at the end of step BC. This research, prior to the synchronous class could help to improve a more specific planning for the DC moment and meet specific needs of the class.

Even with this gap, it is perceptive to comment that one of the functions of the BC moment was fulfilled, as most students managed to gain access and conduct a prior study of the materials provided. The percentage of $9.8 \%$, referring to students who did not previously access the resources offered, can be explained by analyzing some factors, such as: technical difficulty in accessing the material, recurrent material overload in the period of distance education in the pandemic, etc.

In the synchronous DC moment, the aim was to review the concepts, answer students' questions, propose problem 
situations to be solved with the help of simulation software and encourage students to participate in reflections on the content. It can be seen, through teacher observation during classes, that the key points for the synchronous moment were reached, in addition, it is highlighted that the approach used in this step strongly contributed to an increase in participation and teacherstudent interaction. Rodrigues et al. (2021) argue that current situations in many classrooms, lack interaction between teachers and students and have a very low student participation. Therefore, the development of this step of the proposal is of paramount importance for the current moment, in which distance education systems are in effect.

Finally, step AC is dedicated to the assessment of learning. At this time, it was possible to carry out an assessment, through two specific questions from Faraday's Laws, available in a form on the Google Classroom platform. In particular, question 1 was based on an understanding of Faraday's First Law and its numerical application. Numerical applications consist of questions in which students solve the math behind the FLs. It should be noted that, even though question 1 was based on Faraday's 1st Law, knowledge of the two Laws was necessary to interpret and choose the appropriate alternative. Question 2 was based on Faraday's 2nd Law and there was also a quantitative resolution of the same. Table 4 shows, in full, the two questions and their respective alternatives.

Table 4: Questions involving content related to Faraday’s Laws.

\begin{tabular}{|l|}
\hline Question 1 \\
Electrodeposition consists of coating surfaces with metals through \\
the electrolysis process. There are several applications for electrodeposition, \\
due to its various uses, such as, for: decorative purposes, increased \\
durability, protection against corrosion, among others. One of the main \\
applications is silver plating in sports medals in order to cover the surface of \\
the object with the silver metal in its solid form. Suppose that to make the \\
medals for the Olympics, silver plating is done on a surface that initially has \\
a mass of $10 \mathrm{~g}$. Two medals were prepared by electrolysis with the \\
application of a current of 3.5 A for both. The process time for one medal \\
(M1) was 10 minutes and for the other medal (M2) was 20 minutes. Check \\
the CORRECT alternative. (Given: Molar Mass of Silver equal to 107.9 \\
g/mol and the faraday constant (F) equal to 96500 C/mol).
\end{tabular}

A) According to Faraday's First Law, the mass to be deposited in a silver plating process is proportional to the applied charge. Thus, the total mass of each medal after the process is $10.039 \mathrm{~g}$ for M1 and $10.078 \mathrm{~g}$ for M2.

B) According to Faraday's First Law, the mass to be deposited in a silver plating process is proportional to the applied charge. Thus, the total mass of each medal after the process is 9,961 $\mathrm{g}$ for M1 and 9,922 $\mathrm{g}$ for M2.

C) According to Faraday's Second Law, the mass to be deposited in a silver plating process is proportional to the applied charge. Thus, the total mass of each medal after the process is $10.039 \mathrm{~g}$ for M1 and $10.078 \mathrm{~g}$ for M2.

D) According to Faraday's Second Law, the mass to be deposited in a silver plating process is proportional to the applied charge. Thus, the total mass of each medal after the process is $12.35 \mathrm{~g}$ for M1 and $14.70 \mathrm{~g}$ for M2.

E) According to Faraday's First Law, the mass to be deposited in a silver plating process is proportional to the applied charge. Thus, the total mass of each medal after the process is $12.35 \mathrm{~g}$ for M1 and $14.70 \mathrm{~g}$ for $\mathrm{M} 2$.

\section{Question 2}

According to the processes discussed in the previous question, suppose that for the proper preparation of Olympic medals, the time required for electrodeposition of metals on the surface of a medal is 20 minutes and the applied current is 3.5 A. Therefore, when electrodepositing copper $(\mathrm{Cu})$ and silver $(\mathrm{Ag})$ on surfaces with an initial mass of $10 \mathrm{~g}$, we obtain: (Given: Copper Molar Mass equal to $63.55 \mathrm{~g} / \mathrm{mol}$ and the faraday constant (F) equal to $96500 \mathrm{C} / \mathrm{mol}$ )
A) The total mass of the copper medal at the end of the process is 1.3 times greater than the total mass of the silver medal.

B) The total mass of the copper medal, at the end of the process, is 3.4 times greater than the total mass of the silver medal.

C) The total mass of the silver medal at the end of the process is 1.3 times greater than the total mass of the copper medal.

D) The total mass of the silver medal at the end of the process is 3.4 times greater than the total mass of the copper medal.

E) The total masses of the copper and silver medals obtained at the end of the process are equal. 
From the analysis of question 1, it can be said that $68.3 \%$ of the students managed to get the conceptualization and definitions behind Faraday's Laws present in question 1 correct. This percentage refers to the students who marked the alternatives A, B and E, which contain the appropriate conceptual interpretation for question 1 (they managed to understand that it is the 1st FL). Of these students who demonstrated understanding the concepts, $46.3 \%$ managed to get the numerical application of Faraday's Laws correct. Within the rest of the students (31.7\%), that made a mistake in the conceptualization of the Laws, there were cases of students who made a mistake in the conceptual understanding and got the numerical part correct, these cases represent $14.6 \%$ of the students. The conceptual error reflects that the student did not understand that question 1 addresses the 1st FL. There were also situations in which the student had mistaken both the concept and the quantitative part, these represent a percentage of $17.1 \%$.

The interpretation of the data collected on question 2 indicates that $92.7 \%$ of the students chose the correct alternative for the conceptual understanding behind the 2nd FL. On the other hand, $7.3 \%$ of students chose the alternative that demonstrates the misunderstanding of this conceptual part of Faraday's second law. Of the students who got the conceptual part of the question right, 39\% chose the alternative that contemplated the correct numerical application and $53.7 \%$ missed the quantitative part of question 2 .

Figure 3: Graph with the percentages referring to the alternatives of the first and second questions.

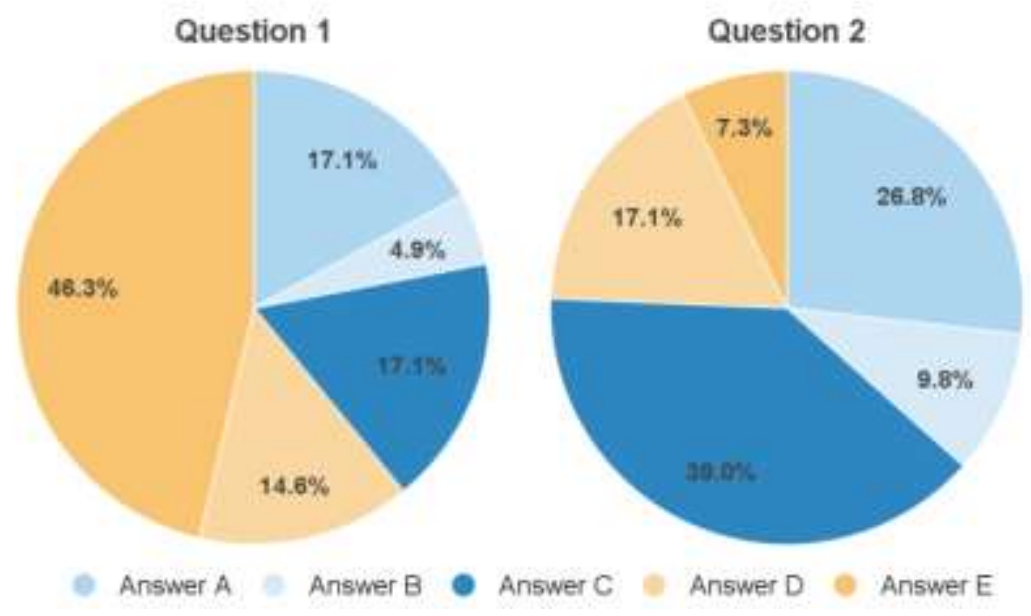

Source: Authors.

In summary, Figure 3 graphically demonstrates the percentages discussed above and, through these interpretations, it can be said that the students demonstrated a good conceptual understanding of Faraday's First and Second Laws. Despite this, the skills related to the numerical application of Faraday's Laws did not achieve the same success in terms of statistics. Therefore, this is a point of reflection so that future applications of this proposal can be planned and adapted in order to develop a greater depth in the numerical part of Faraday's Laws. It is noteworthy that the analytical movement of these two questions seeks to weave articulations between the organization of the tools used and the activities implemented in the Flipped Classroom and the content addressed (Faraday's Laws), which do not allow the development of further inferences regarding evidence of learning.

\section{Final Considerations}

The work developed used the Flipped Classroom as a methodological tool for teaching Chemistry, especially in teaching Faraday's Laws to High School students. 
Another focus of the work was to carry out a mapping of scientific articles that contained teaching proposals based on the FC methodology and/or with the topic addressed. This mapping evidenced a relatively small amount of articles (13) on Faraday's Laws and the FC. From these articles, it was noted that there is a lack of studies that address Faraday's Laws within the electrolysis contents, there is also an absence of articles that contain the Flipped Classroom methodology in Chemistry Teaching and there is no study that uses the FC in teaching content related to FLs. Thus, the bibliographical research carried out shows that the present article can be considered a pioneer study, regarding the teaching of Faraday's Laws using the FC within the Teaching of Chemistry.

Overall, it can be concluded that the application of the chosen FC approach, with a variety of teaching resources, was satisfactory, as a significant increase in student participation during synchronous classes and the strengthening of the teacherstudent relationship was noticed. It is important to highlight that the proposal was designed to be implemented in the local reality, taking into account the pedagogical guidelines of the school context in question. Therefore, it refers to a punctual implementation, showing possibilities for adjustments and modifications through application to other contexts. With the data collected in the third moment (AC), it was noticed that the three steps of the Flipped Classroom managed to fulfill their functionalities. Also, it was noted that the three steps of the methodology helped in the conceptual understanding of the two Faraday Laws.

Finally, the results of this investigation highlight the potential of using the Flipped Classroom in terms of its methodological versatility for the distance education modality, considering the current pandemic context. It is noted that the methodology used is a prominent choice for teaching Faraday's Laws, as well as being used in teaching various other contents, requiring intentional prior planning.

\section{References}

Assai, N. D. S., Arrigo, V., \& Broietti, F. C. D. (2018). Uma proposta de mapeamento em periódicos nacionais da área de ensino de ciências. REPPE-Revista de Produtos Educacionais e Pesquisas em Ensino, 2(1), 150-166. http://seer.uenp.edu.br/index.php/reppe/article/view/1380/675

Barão, G. C. (2007). Ensino de Química em ambientes virtuais. In: Paraná. Secretaria de Estado da Educação. Superintendência de Educação. O professor PDE e os desafios da escola pública paranaense. SEED/PR. http://www.gestaoescolar.diaadia.pr.gov.br/modules/conteudo/ conteudo.php?conteudo=616.

Bergmann, J., \& Sams, A. (2012) Flip your Classroom: Reach Every Student in Every Class Every Day. ISTE, ASCD.

Braga, M. B. S. (2019). Ensino de Eletroquímica no Ensino Médio em uma abordagem CTS. [Course Conclusion Paper, Institute of Chemistry, University of Brasília]. Biblioteca Digital da Produção Intelectual Discente. https://bdm.unb.br/handle/10483/22460

Carvalho, L. H. P., \& Candeias, C. N. B. (2016). O uso de videoaulas como ferramenta no processo de ensino e aprendizagem em química. Paper presented in the $7^{\circ}$ Simpósio Internacional de Educação e Comunicação-SIMEDUC. Aracaju, Sergipe. https://eventos.set.edu.br/simeduc/article/view/3306

Costa, S. L. R., Obara, C. E., \& Broietti, F. C. D. (2020). Critical thinking in Science education and Mathematics education: research trends of 20102019. Research, Society and Development, 9(9), 1-30. https://doi.org/10.33448/rsd-v9i9.6706

Ennis, R. H. (1985). A logical basis for measuring critical thinking skills. Educational leadership, 43(2), 44-48.

Fiori, R., \& Goi, M. E. J. (2020). O Ensino de Química na plataforma digital em tempos de Coronavírus. Revista Thema, 18, 218-242. https://doi.org/10.15536/thema.V18.Especial.2020.218-242.1807

Giordan, M. (2008). Computadores e linguagens nas aulas de ciências: uma perspectiva sociocultural para compreender a construção de significados. Editora Unijuí.

Leite, B. S. (2017). Sala de aula invertida: uma análise das contribuições e de perspectivas para o Ensino de Química. Paper presented in the X Congreso Internacional dobre Investigaciónen Didáctica de Las Ciencias. Sevilla, Spain. https://raco.cat/index.php/Ensenanza/article/view/337101/427970

Lopes, S. F. S. F., Gouveia, L. M. B., \& da Cunha Reis, P. A. (2020). O método MaCAIES: uma proposta metodológica para a implementação da sala de aula invertida no Ensino Superior. Research, Society and Development, 9(1), 1-17. http://dx.doi.org/10.33448/rsd-v9i1.1921

Mello, I. C. (2009) O ensino de química em ambientes virtuais. EdUFMT.

Melo, E. S. N., \& Melo, J. R. F. (2005) Softwares de simulação no Ensino de Química: Uma Representação Social na Prática Docente. Educação Temática Digital, 6(2), 51-63. 
Research, Society and Development, v. 10, n. 9, e50410918118, 2021

(CC BY 4.0) | ISSN 2525-3409 | DOI: http://dx.doi.org/10.33448/rsd-v10i9.18118

Merçon, F, Souza, C. M. S. V., Pereira, J. A. S., Silva, J. A. S., \& Conceição, R. E. (2012). Estratégias Didáticas no Ensino de Química. e-Mosaicos - Revista Multidisciplinar de Ensino Pesquisa e Cultura (CAp - UERJ), l(1), 78-93. https://doi.org/10.12957/e-mosaicos.2012.4386

Moran, K., \& Milsom, A. (2015). The Flipped Classroom in Counselor Education. Counselor Education and Supervision, 54(1), 32-43. https://doi.org/10.1002/j.1556-6978.2015.00068.x

Neder, M. L. C. (2009). Planejando o Texto Didático Específico ou o Guia Didático para a EaD. In: Possari, L.H. V., Neder, M. L.C. Material Didático para a $E a D$ : Processo de Produção. Cuiabá: EdUFMT.

Oliveira, E. S., Reis, N. A., \& Silva, E. L. (2018). Contextualização histórica dos estudos de faraday sobre eletricidade e matéria: contribuições para o Ensino de Ciências. Revista de Ensino de Ciências e Matemática, 9(3), 87-105. https://doi.org/10.26843/rencima.v9i3.1527

Pinto, M. F. (2018). Da eletricidade nos séculos XVII e XVIIII às Leis Eletroquímicas de Michael Faraday. [Dissertation, Federal University of Juiz de Fora]. Juiz de Fora. Repositório Institucional UFJF. https://repositorio.ufjf.br/jspui/handle/ufjf/7244

Rodrigues, N. C., Souza, N. R., Patias, S. G. O., Carvalho, E. T., Carbo, L. \& Santos, A. F. S. (2021). Recursos didáticos digitais para o ensino de Química durante a pandemia da Covid-19. Research, Society and Development, 10(4), 1-17. http://dx.doi.org/10.33448/rsd-v10i4.13978

Schmitz, E. X. S. (2016). Sala de Aula Invertida: Uma abordagem para combinar metodologias ativas e engajar alunos no processo de ensino-aprendizagem. [Dissertation, Federal University of Santa Maria], Santa Maria. Manancial Repositório Digital da UFSM. https://repositorio.ufsm.br/handle/1/12043

Schultz, D., Duffield, S., Rasmussen, S. C., \& Wageman, J. (2014). Effects of the flipped classroom model on student performance for advanced placement high school chemistry students. Journal of chemical education, 91(9), 1334-1339. https://doi.org/10.1021/ed400868x

Silva, C. R. F. Santos, A. L. B. S. \& Silva, G. N. (2019). Possibilidades de uso de Artigos Acadêmicos em Curso de Licenciatura em Química à Distância. In C. L. Voigt (Ed.). O Ensino de Química (pp. 213-226). Atena Editora.

Valente, J. A. (2018). A sala de aula invertida e a possibilidade do ensino personalizado: uma experiência com a graduação em midialogia. Metodologias ativas para uma educação inovadora: uma abordagem teórico-prática. Porto Alegre: Penso, 26-44.

Vieira, L. M. \& Guimarães, R. L. (2015). Jogos no Ensino de Química: desenvolvimento de jogos didáticos no Ensino de Química Orgânica para o Ensino Médio. Paper presented in the XXXIII CONIC, VII CONITI, IV ENIC.

Vieira, W. E. S., Melo, H. D. F. \& Viana, K. S. L. (2018). Estratégias Didáticas no Ensino de Química: Concepções e Práticas do Profissional da Educação e Suas Relações com a Aprendizagem de Conceitos. Paper presented in the $V$ CONEDU - Congresso Nacional de Educação, Olinda, Pernambuco. https://editorarealize.com.br/editora/anais/conedu/2018/TRABALHO_EV117_MD1_SA1_ID565_08092018234209.pdf 